OPEN ACCESS

Edited by:

Danielle E. Endres,

University of Utah, USA

Reviewed by:

Casey R. Schmitt,

Lakeland College, USA

Jennifer Peeples,

Utah State University, USA

*Correspondence:

Tracylee Clarke

tracylee.clarke@csuci.edu

Specialty section:

This article was submitted to Science and Environmental Communication,

a section of the journal

Frontiers in Communication

Received: 18 July 2016 Accepted: 13 January 2017

Published: 01 February 2017

Citation:

Clarke T (2017) The Construction of Goshute Political Identity: Negotiation of Voice Regarding Nuclear Waste Policy Development.

Front. Commun. 2:2.

doi: $10.3389 /$ fcomm.2017.00002

\section{The Construction of Goshute Political Identity: Negotiation of Voice Regarding Nuclear Waste Policy Development}

\author{
Tracylee Clarke* \\ California State University Channel Islands, Communication, Camarillo, CA, USA
}

This article examines the relationship between political identity and voice through an analysis of conflict between members of the same Native American nation over the development of environmental policy. Grounding this study in the work of Paul Ricoeur and his theory of narrated identity and using Senecah's "Trinity of Voice" as an organizing analytical framework, I examine communication and negotiation of voice among members of the Skull Valley Goshute tribe regarding the storing of nuclear waste on their reservation. I argue that tribal members' identities are constructed through political narratives about voice (or lack thereof), complicating their sense of self and creating a complex forum for tribal nuclear waste policy development and decision making. This article contributes to our theoretical understanding of political voice and identity, revealing its implications for nuclear waste policy development. Further, it provides a deeper understanding of the complexities of environmental conflicts within Native American communities.

Keywords: environmental policy development, Goshute Native Americans, nuclear waste, political identity, Ricoeur narrative

\section{INTRODUCTION}

In 2010, President Obama appointed the Blue Ribbon Commission on American's Nuclear Future (BRC) to study options for dealing with nuclear waste as alternatives to replace permanent disposal at Yucca Mountain, NV, USA. The management of America's nuclear waste is one of the most pressing environmental problems we face (Taylor, 2003; Taylor and Kinsella, 2007; Endres, 2009c; Burger et al., 2010b; Pajo, 2016). Even without a planned expansion in nuclear power generation, there remains approximately 2,400 metric tons of waste produced annually in addition to the existing 65,000 metric tons that lack permanent storage (Sovacool and Funk, 2013; Alley and Alley, 2014; Nelson, 2014). In 2012, the BRC recommended a new voluntary program for siting repositories involving states, municipalities, and Native American tribes (Nuclear Regulatory Commission, 2012; Funk and Sovacool, 2013; Sovacool and Funk, 2013; Nelson, 2014). The BRC report advocated a "new consent-based approach to siting future nuclear waste management facilities," the creation of a new agency to manage nuclear waste and the development of storage facilities alongside repositories (Nuclear Regulatory Commission, 2012, p. 8). Since the BRC issued its report, Senator Ron Wyden (D-OR) introduced S.1240, the Nuclear Waste Administration Act of 2013, in the 113th Congress in order to create an agency to implement the consent-based approach. The bill specified a preference for the co-location of storage facilities and repositories 
(Nelson, 2014). Committed to consent-based siting, the Office of Nuclear Energy is in the process of engaging with state, local, and tribal communities to learn and document what elements are important in designing and implementing a consent-based siting process. This feedback will serve as a framework for the Office of Nuclear Energy and will guide how they work with interested host communities in the siting of nuclear waste storage facilities (Consent-Based Approach, 2016; http://www.energy. gov/ne/consent-based-approach).

The development of the BRC report and the introduction of S.1240 requires a reconsideration of the relationship between Native American communities and nuclear waste storage (Alley and Alley, 2014; Nelson, 2014). Central to that issue are the cultural, political, and environmental ramifications of placing nuclear waste management facilities on Native American reservations and the role of Native American tribes in the management of our nation's nuclear waste (Kuletz, 1998; LaDuke, 2001; Clarke, 2002, 2010; Lewis, 2007; Endres, 2009a,b; Burger et al., 2010a; Nelson, 2014; Pajo, 2016).

Acknowledgment of the political voice of tribal members and meaningful involvement in tribal decisions regarding management and storage is critical in nuclear waste policy development (Clarke, 2010; Nelson, 2014). Huspek and Kendall (1991) define political voice as "the expression and contestation of values, norms, interests, and policies" wherein citizens are able to "exercise control over the conditions of their existence" (p. 1). This expression must be heard, acknowledged, and validated. Couldry (2010) distinguishes between two levels of voice: voice as process and voice as value. As process, voice is the chance to give an account of oneself, to be heard and acknowledged. It requires "listening ... an act of attention that registers the uniqueness of another's narrative ... socially grounded, preformed through exchange, reflexive, embodied, and dependent upon a material form" (pp. 9, 91). This social exchange necessitates what Couldry identifies as the second level of voice: value, giving merit to structures or avenues that support the articulation of one's accounts. The point Couldry is making is that more than just being heard, voice must matter and have impact. Lewis (1995) argues that in terms of political voice, nuclear waste management opportunities "may be the most serious threat to the long term welfare of native peoples" (p. 433). The voices of tribal members regarding the impact of such policy on their cultural and political lives and their relationship with the natural world must be recognized. More than just an issue of environmental justice, political voice creates social legitimacy and the assurance that tribal members will be heard and their concerns will be taken into consideration and addressed through policy development processes (Agrawal, 1995; Nadasdy, 1999; Blowers, 2000; Kinsella, 2004; Rosa and Short, 2004; Endres, 2009a,b; Burger et al., 2010b; Nelson, 2014).

Understanding how political voice gets negotiated among members of Native American tribes becomes crucial in not only understanding nuclear waste policy development but also the impact of such policies on tribal members. Thus, this article examines the communication and negotiation of political voice among members of the Skull Valley Goshute tribe, one of several tribes considering working with the Nuclear Waste Negotiation $(\mathrm{NWN})$ but the only tribe to enter into negotiations with the
NWN and later a private consortium of utilities to lease a private storage facility on their reservation. During the application and licensing process, Goshute tribal members were bitterly divided in their support for the proposal (Hengesbaugh, 2000; Fahys, 2007, 2011). Tribal members who opposed the proposal brought suit against those who supported it, arguing that the leaders who signed the agreement acted without authority, misrepresenting the desires of tribal members (Costanzo, 1999). Their anger was fueled by the belief that they were not given the necessary information to make an informed decision nor the opportunity to voice concerns through an internal tribal democratic process. Those in support of the proposal, however, believed they were given adequate information, were encouraged by the Private Fuel Storage (PFS) and the council to become educated and involved, and were given a voice through traditional avenues such as tribal council meetings and project updates (Costanzo, 1999; Peeples et al., 2008). The different and opposing experiences of tribal members created irreconcilable conflict among the Skull Valley Goshutes (Clarke, 2002).

Scholars studying Native American political conflicts have argued that for some Native American tribes and individuals, exercise of their political voice is an act of survival directly tied to their political identity (Deloria, 1985; Nagel, 1996; Watts, 2001; Boholm and Lofstedt, 2004; Grand, 2004). Political identity defined as one's sense of self in relation to the public sphere is directly linked to access to resources, political mobilization, and power. For tribal members, it is, in a sense, the ability to be heard and influence the political direction of their tribe. Tribal political identity is a "condition of survival and its implications may be grasped only by reference to structures of power" (Dirlik, 2000 , p. 81). Underlying and intensifying the Goshute controversy and fight for political voice is deeply contested Goshute political identity (Lewis, 2007; Clarke, 2008; Peeples et al., 2008). Representatives on opposing sides speak of their political identity in terms of a survival of self and political power. In an interview, Margene Bullcreek said the proposal is "a mockery to Native Americans, to who we are as Goshutes" (as cited in Spangler, 1998, para. 1). Later, she references structures of power and states her biggest concern is lack of political involvement, "It's a dictatorship. There was no vote and there's no information. Bear won't tell the people what's going on" (M. Bullcreek as cited in Cates, 1998, para. 1). In a similar fashion, Leon Bear, a proponent of the proposal, speaks of political identity and the Goshutes' right to develop policy and decide their own fate: "The Goshute Indians should have a right to decide if having a nuclear waste dump next door is what we want to have happen. We are the ones who should be in charge of our tribe and our destiny" (as cited in Dickson, 2000, p. 23). For both of these tribal members, the crucial issue is voice. Bullcreek claims her and other tribal members' sense of self is compromised by lack of political voice and influence on tribal decisions. Likewise, Bear ties political voice and decision-making to tribal destiny, purpose, and identity. Political identity is directly linked to political voice or the ability to be heard and exercise political power.

Using the Skull Valley Goshutes as a case study, I seek to better understand the implications of political voice on tribal members' identity within the internal nuclear waste policy 
decision-making process of the Skull Valley Goshute governing council. Grounding my analysis in the work of Paul Ricoeur and his theory of narrated identity, I examine tribal members' narratives regarding the storing of nuclear waste on their reservation and argue their identities are constructed through political narratives about voice (or lack thereof) complicating their sense of self and creating a complex forum for tribal nuclear waste policy development and decision-making. While Ricoeur's narrated identity is my main theoretical lens, I use Senecah's "Trinity of Voice" as an analytical framework to organize and operationalize Ricoeur and to highlight the decision-making process elements necessary for tribal members' political voice to be realized within tribal nuclear waste policy development.

\section{THE SKULL VALLEY GOSHUTES NUCLEAR WASTE CONTROVERSY}

In 1987, the Office of NWN under the direction of the federal government sought a community to voluntarily store nuclear waste. The program, known as MRS, would temporarily store 40,000 metric tons of spent nuclear fuel within a designated community until a permanent storage location could be determined. In 1992, the Skull Valley Goshutes, a small tribe located in southwest Utah, submitted a grant application and were awarded $\$ 100,000$ to investigate the benefits and impacts of implementing the MRS program on their reservation. In 1997, the Skull Valley Goshutes signed a deal allowing high-level nuclear waste storage on their reservation, becoming one of the project's Phase II applicants and later after the NWN was dissolved, the first Native American tribe to enter into negotiations with the PFS Consortium (Clarke, 2008; Nelson, 2014).

Shortly after the application and licensing process began, strong opposition to the proposal came from within the tribe. More than half of the Goshutes living on the Skull Valley reservation joined in a lawsuit to have the tribe's lease with a nuclear waste storage firm declared null and void. The lawsuit charged that the Department of Interior Bureau of Indian Affairs (BIA) put a rush on the review process and approved the lease even though it was aware of improprieties, including conflict of interest, lack of authority, and unlawful acts. The lawsuit also contended that tribal leaders who signed the documents acted without authority as the proposal was never approved by the Tribal General Council and only represented the interests of a minority of the tribe (Costanzo, 1999). Further, tribal members said they were not given enough information to make an informed decision about the lease, nor the opportunity to voice concerns through a democratic process (Kemp, 1999). This was countered by those in support of the proposal who believed they were given adequate information, encouraged by the PFS and the council to become educated and involved, and were given a voice through traditional avenues, such as tribal council meetings and project updates (Costanzo, 1999; Peeples et al., 2008).

In spring 2000, accusations of fraud and bribery began to surface among tribal members resulting in another lawsuit against Leon Bear, Goshute tribal chairman and the biggest proponent of the nuclear waste proposal. Bear was accused by members of the tribe of trying to blackmail them to support his cause. Margene Bullcreek and Sammy Blackbear, leaders of the opposition to the proposal, alleged that Bear threatened to withhold the annual tribal dividend payments to some members unless they voted for the proposal, while paying other tribal members large sums of money for their support (Hengesbaugh, 2000).

Opposition to Bear as the tribal chairman led to a call for a tribal reelection in the fall of 2000 . Those candidates challenging incumbent tribal chairman Bear promised tribal members they would stop the nuclear waste proposal. However, in late November, Bear was re-elected to a second 4-year term. Tribal members who opposed Bear's leadership and the nuclear waste proposal boycotted the election arguing that only 37 of the tribe's 70 eligible voting members cast ballots making the election void. The results of the election, however, were recognized by the BIA and Bear remained the official tribal chairman of the Skull Valley Goshutes (Israelsen, 2000a,b). In the summer of 2001, those opposed to the nuclear waste proposal again challenged the election by circulating a resolution that recalled Bear as tribal chairman. They argued that Bear had alienated tribal members and withheld important documents related to the nuclear waste proposal. Bear responded that he was acting in the best interest of the tribe and needed to protect certain documents from those who opposed the proposal (Israelsen, 2001a,b). Seeking access to information and a voice in tribal decisions related to the nuclear waste proposal, those in opposition held their own election for a new tribal chairman. This election, however, was not recognized by the BIA who continued to view Bear as the rightful chairman (Israelsen, 2001c; Santini, 2001; Fahys, 2002a).

In the fall of 2002, tribal members petitioned the NRC to stop the licensing process until internal political conflicts were resolved. The NRC ruled it had no jurisdiction over internal tribal disputes (Fahys, 2002b). Bear and his supporters retaliated against tribal dissidents, and in late summer 2003, members of the tribe who continued to speak out against tribal leadership and their decisions to store nuclear waste were charged with treason and their tribal membership was threatened (Fahys, 2003; Urbani, 2003).

In 2006, the proposal to store nuclear waste on their reservation was denied by the BIA. Skull Valley Goshutes tribal leaders responded by suing the BIA in US District Court for the District of Utah. In 2010, the case Skull Valley Band of Goshute Indians v. Davis was heard, and the court ruled in favor of the Goshutes determining the BIA's denial of the project was not legally standing (Burr, 2011; Nelson, 2014). Since then, however, there have been no plans to issue another policy decision, and the PFS has not indicated they will seek to reopen negotiations with the Skull Valley Goshutes. ${ }^{1}$

In this new era of waste management and the Office of Nuclear Energy's commitment to community engagement and collaborative consent-based siting, understanding how tribal members negotiate voice within internal tribal decision-making processes

${ }^{1}$ For additional review of the intra-tribal conflict among the Skull Valley Goshutes over the storing of nuclear waste on their reservation, see Clarke (2008), (2010) Endres (2009b), Lewis (2007), Nelson (2014), and Peeples et al. (2008). 
becomes critical and timely. Thus, reflecting on and analyzing the intra-tribal conflict surrounding nuclear waste management policy among the Skull Valley Goshutes can give insight about the implications of such negotiations on community members, both tribal and non-tribal, and the interplay between voice and political identity. Further, it can shed light on the necessary engagement and process elements of a consent-based approach to nuclear waste policy development.

\section{VOICE AND POLITICAL IDENTITY}

Communication scholars recognize the importance of voice and its connection to the environment. In their book Voice and the Environment, Peeples and Depoe (2014) explore the relationship between voice and the environment; how voice is sought, enacted, constrained, and obstructed. They argue that all too often in attending to environmental issues, "what is missing is acknowledged voice, one that is given an audience, allowed to be impactful and transformative in its assertions-one that is heard" (p. 1), or to reference Couldry (2010), one that matters and has impact. Engaging communication scholars who study voice and its relation to advocacy, identity, social organization, and political process, Peeples and Depoe argue, "Voice is power" and "the currency of environmental struggle" (p. 2). Of particular interest to this essay is the power and currency of voice in environmental policy development and decision-making. Senecah (2004) introduces the practical theory of "Trinity of Voice"-access, standing, and influence-as an effective standard to analyze environmental policy development and address citizens' needs to be heard and have a meaningful role in determining the political future of their communities. Voice, argues Senecah, is comprised of three critical elements: access to information, education, and assistance to actively participate in decision-making; standing or civic legitimacy, which translates into respect; and influence, the authentic ability to influence decisions.

Access to information and data are at the core of involvement of people and communities in decision-making concerning environmental issues (Depoe and Delicath, 2004; Kinsella, 2004; Cox, 2006; Clarke et al., 2015). Access also refers to appropriate support such as resources and may also include education, training, and capacity building (Burger et al., 2010a). While access alone is not enough, it forms the basis for voice and is critical to any policy development process. Standing, or civic legitimacy, involves respect and the authentic consideration of stakeholders' perspectives. It is the inclusion of individuals as equals in the decisionmaking process, whose knowledge is deemed socially, culturally, and politically legitimate (Klassen and Feldbausch-Parker, 2011; Chen et al., 2012). Access and standing are mutually dependent on each other and necessary to achieve influence. Influence does not mean that participants get what they want. Rather it refers to the respectful consideration of the concerns and ideas of all participants and the ability to determine the outcome of a policy decision (Stöhr et al., 2014; Clarke et al., 2015).

The trinity of voice theory argues that when access, standing, and influence are present, it establishes trust, which is the foundation for building effective and socially legitimate policy development (Beierle and Cayford, 2002; Senecah, 2004). Trust is cultivated by the open sharing of correct information, involvement, and the ability to influence decisions. Riley (2004) asserts that trust and choice is of utmost importance in nuclear waste policy development, and nuclear waste policy makers will find it difficult to develop legitimate policy without it. Further, voice creates ownership of not only the process but also policy decisions, thus reducing conflict and strengthening relationships between and within communities (Senecah, 2004; Walker et al., 2006; Martin, 2007; Singh et al., 2007).

Using the trinity of voice as an analytical framework for discovering limitations or weaknesses in tribal involvement in nuclear waste management policy development highlights the necessary process elements for tribal members' political voice to be realized. It speaks to the structural elements of decision-making within the tribe that support or negate individual tribal voice. This, however, is only the first step. It does not illustrate the impact of voice (or lack thereof) on tribal members' political identity nor does it demonstrate how political identity is negotiated within political decision-making processes. For a deeper understanding of the relationship between voice, political identity, and policy development, I turn to narrative analysis.

Bruner (1996) argues that identity narratives are used to gain voice, justify behavior and intentions, and achieve particular political goals. But the connection between identity, narrative, and voice is much richer than this. Narrative is more than a means to express political identity in order to gain voice, it is the means by which identity is constructed and voice becomes realized. The very opportunity of voice directly influences a sense of self and the construction of an individual's identity. Peeples and Depoe (2014) argue, "through the practice of giving an account, the speaker is also constructing his or her identity, place, and life experiences. The expression of and constitution of a life story are intertwined and inseparable throughout the process of giving voice" (p. 3). Carbaugh (1996) also makes the direct link between voice, identity, and narrative. He argues that conversational moves, such as narrative, help individuals make claims about their identity. This explication of identity is how one finds voice. The speaker must speak and be heard, and his or her words or constructed identity must be ratified by others. If it is not ratified, but rather rejected, then one's voice or identity is refused. The communicative process of narrative is then, according to Carbaugh, necessary for the "constitution of voice" (p. 146). Thus, an analysis of Goshute tribal members' narratives about access, standing, and influence regarding the nuclear waste project illuminates how their voice is realized, ratified, or rejected in turn constructing their political identity. To further explain the relationship between narrative, identity, and voice, I rely on French philosopher Paul Ricoeur and his theory of narrated identity.

Ricoeur argues that one's very experience of identity, or of being, has a narrative structure (Ricoeur, 1983, 1984, 1985, 1989, 1991a,b, 1992). Narrative, for Ricoeur, is the linguistic form through which we express the temporal dimensions of human life. Identity is constructed and reconstructed through a process he calls emplotment, a perpetual weaving and reweaving of past and present events into characters, motives, situations, and actions. Emplotment is the "synthesis between events or incidents which are multiple and the story which is unified and complete" 
(Ricoeur, 1991b, p. 21). The plot thus acts as an organizer of events into a coherent story, and people become characters in the stories they keep revising and retelling as their lives unfold. The construction of narratives is fueled by the tension between what Ricoeur (1991b) calls concordance and disconcordance-or the need for unity and coherency in diverse, fragmented, and unstable life experiences: it is the need for synchronicity that drives the telling of narratives. Narrative, then, becomes a mechanism to know oneself and make sense of lived experience.

Ricoeur (1983) argues that action is that aspect of human behavior that can be recollected in stories whose function, in turn, provides an identity to the actor. It is not enough, however, to merely assess who acts within a narrative. The actions of those in the narrative must be appraised in light of an actor's ability or agency to act. It is the actor's intentionality that counts. In narrative intentions and motives are assigned to the actor and become the basis for judgment of the actor. Actions, understood as deliberate, then become "subject to approval or disapproval" and actors and agents become "subject to praise or blame" (Ricoeur, 1989, p. 164). Ricoeur (1992) extends the concept of action and agency by reminding the reader that the other side of action is suffering. "Narrative is the imitation of action. At the same time, and correlatively, the subject of the action recounted will begin to correspond to the broader concept of the acting and suffering individual" (p. 18). Identity is established through a narrative interpretation of who is empowered or constrained to act, who is acted upon, and so forth. Narrative evaluation of an action leads to characterizing oneself as an agent of action or a victim of the actions of others. Personal narratives provide the communicative basis for connecting agency and suffering with identity; they enable a speaker to interpret himself or herself as an agent and sufferer in relation to social others and social conditions. It is this aspect of narrative that speaks directly to identity construction. It is through our narratives that we "apply to actions a moral judgment of imputation" (Ricoeur, 1989, p. 101) and engage in the act of accusing or attributing a result to a particular person or cause in which case we become the victim or, in Ricoeur's words, the sufferer. Narrative, then, is the "lived interpretation of self as actor and sufferer” (Brown, 1997, p. 110). Ricoeur's distinction between empowerment and suffering becomes important in our understanding of Goshute tribal members' construction of political identity and its impact on nuclear waste policy development. If the nuclear waste proposal presents process or structural opportunities to give input (access, standing, and influence), then voice is attained and tribal members become agents and are empowered. If, however, the project or policy opportunities limit their voice, then tribal members become victims of the actions of others, or in Ricoeur's words, sufferers. Thus, their political identity is directly impacted by structural opportunities of access, standing, and influence.

Examining the Goshute case using Senecah's "Trinity of Voice" alone gives us only part of the picture; an understanding of the necessary process elements in tribal nuclear policy development. By integrating Senecah's "Trinity of Voice" with Ricoeur's narrated identity in our analysis, we understand not only the structural process elements necessary to grant voice in environmental policy development but also how those structural elements work to influence the construction of tribal members' political identity, further complicating nuclear waste policy development on tribal lands. Harper (2001) argues that understanding environmental narratives allows researchers to "uncover how the environment is constructed through political processes and who benefits or suffers from these constructions" (p. 102). Thus, a combined analytical approach contributes to our theoretical understanding of the interplay between narrative, voice, and identity, revealing its implications for nuclear waste policy development in general and provides a deeper understanding of the complexities of environmental conflicts within Native American communities.

\section{METHODOLOGICAL APPROACH: GOSHUTE NARRATIVE ANALYSIS}

I ground my analysis in the work of Paul Ricoeur and his theory of narrated identity and examine tribal members' narratives regarding the storing of nuclear waste on their reservation. While Ricoeur's narrated identity is my main theoretical lens, I use Senecah's "Trinity of Voice" as an analytical framework to organize and operationalize Ricoeur. Providing a common language of description, Ricoeur's theory offers a methodological tool to understand tribal members' political identity narratives highlighting the importance of access, standing, and influence for political voice.

\section{Data Gathering}

Goshute discourse about the storage of nuclear waste on their reservation was gathered from multiple sources during the application and licensing process. Interviews with tribal members about the nuclear waste project were conducted and transcribed during 2000 to 2002 during the licensing phase of the project. Tribal members were asked about the project in general and the economic, cultural, and political implications of the nuclear waste proposal. Tribal members were not asked specifically about the internal decision-making process of the tribe nor were they questioned about their political identity. In addition to interviews, public testimonies of tribal members were also analyzed. The National Environmental Policy Act (NEPA) requires all activities on federal land or associated with federal monies to go through a process to assess the impact on the social, natural, and human environment. The NRC, whose charge it was to grant the procedure permit and author a record of decision relating to the Goshute nuclear waste project, hosted public hearings toward the beginning of the scoping process designed to identify issues relating to the proposed project and again toward the end of the NEPA process after a draft Environmental Impact Statement had been issued. At 10 of those public hearings, held between the summer of 1998 and the spring of 2002, tribal members gave their testimonies and told of the impact the nuclear waste proposal would have on their reservation and their political and cultural lives. These unedited transcribed testimonials provided additional personal narratives about their support or opposition to the NRC licensing process and the internal decision-making of the tribe in relation to the proposal. Although the NRC licensing process is external to policy decisions within the tribe, tribal members' testimonials remain relevant as the hearing process was used to 
vocalize not only support or opposition for the project in general but the implications of the internal conflict and decision-making process. Tribal documents including newsletters and policy statements from the Skull Valley Tribal Executive Council, which outlined the history of the Goshutes, their political and economic state, and arguments in support of the nuclear waste proposal and tribal policy for development projects on reservation land were also analyzed. Finally, secondary source material in the Salt Lake Tribune, Deseret News, City Weekly and other local and national papers from the onset of the application process in 1991-2011 were analyzed. With the exception of editorials, newspaper quotes were used as a secondary resource to confirm already articulated narratives and supplement interviews and testimonials. These multiple sources create a robust understanding of the nuclear waste controversy and the ways in which political power and identity were enacted, expressed, described, or legitimated through tribal members' discourse about nuclear waste on their reservation.

Taylor et al. (2005) claim that to understand nuclear policy making, research must focus on the specific "micropractices of participants" (p. 382). Tribal narratives gathered from interviews, testimonials, and news reports provide such micropractices and help us understand how the Skull Valley Goshutes negotiate political voice during their internal tribal policy development processes. Paying attention to such practices can illustrate the implications of communication on policy development, providing a more comprehensive understanding of the relationship between Native Americans and nuclear waste. Understanding the structural and political processes and dynamics present during the initial stages of the tribe's nuclear waste policy development and the impact of the ensuing conflict can give insight into the implications of such negotiations on community members, both tribal and non-tribal. Admittedly, this data set is older as the primary and secondary data sources were gathered over 10 years ago. However, in light of the Office of Nuclear Energy's recent commitment to community engagement and collaborative consent-based siting, understanding the history of the Goshute's intra-tribal conflict and how tribal members negotiated voice within internal tribal decision-making processes becomes timely.

\section{Data Analysis}

As suggested by Alasuutari (1995), the observations made through the analysis of interview data were not treated as results, but as clues considered from a particular, explicitly defined point of view. The first layer of my analysis focused on identifying political narratives within the data set. Comments within shared narratives gave insight into the type of narrative and its influence on tribal identity. For example, "Although there are Native American people who oppose the storage of radioactive materials on their reservation, this is a matter to be determined by the sovereignty of each tribal government" (Cesspooch, 1998, p. 1) refers to the political independent control of the tribe and was coded as a political narrative. I then identified themes within each political narrative (access, standing, and influence). The object of my categorizations was to provide a list of possibilities that might provide access to the assumptions and beliefs held by the informants (Geertz, 1976).
After tribal narratives were coded, Ricoeur's theory of narrated identity was used as an interpretive lens to understand implications for political identity construction. I first identified acts of emplotment: meaningful sequence of events, actors, and actions shared by the participants. For example, a sequence of events may be an account of tribal leader Leon Bear applying for the grant to store nuclear waste on the reservation followed by allegations of fraud and bribery by certain tribal members. These two events related in time constitute what Ricoeur terms emplotment. Bear and other tribal members are identified as actors and applying for the grant and allegations of fraud identified as actions.

After identifying emplotment, I then identified the intent and motives assigned to the actor as well as the perceived constraints or effects on the narrator. Assigning intent to the actor sounded like, "That's a sellout that our chairman is giving our people. Leon may have started out with the best interest of his tribe, but money corrupts" (Bullcreek as cited in Dickson, 2000, p. 24). Intentions are evaluated and either praised or blamed as the actor becomes morally impugned and the narrator is either empowered as an agent, or victimized as a sufferer. In this example, Bear is morally impugned for selling out and tribal members become victims of his actions and lose voice (standing and influence). This impacts not only how policy gets developed on their reservation but also how the self gets negotiated and ultimately challenges tribal members' political identity. It is important to note that, for Ricoeur, narratives rarely come forth as whole stories but are fragmented statements that unfold in the telling of an experience over time. Thus, comments are often splintered and incomplete as the self is fragmented among multiple accounts.

\section{POLITICAL NARRATIVES OF VOICE AND THE CONSTRUCTION OF GOSHUTE IDENTITY}

It's a dictatorship. There was no vote and there's no information (Bullcreek as cited in Cates, 1998, para. 1)

Our people are as one, our voice is as one (Interview 11, May 15, 2002).

Nagel (1996) argues that for some Native Americans, access to resources and political mobilization or the ability to influence decisions are critical elements of their political identity. As a product of political context, the self in narrative responds to political conditions and existing power relations and hierarchies. For many Goshute tribal members, the existing power relations within the tribe and larger social political context limit their access to information and resources, severely restricting their opportunity to be involved in political matters of the tribe, influence policy development, or have their voice heard. For others, however, the project seemingly allowed voice through access, standing, and influence and their narratives of voice articulate an empowerment. In both cases, narratives about the nuclear waste proposal articulate a sense of self in relation to voice constructing and reconstructing tribal members' political identity. 


\section{Narratives of Access}

In Goshute narratives about the MRS proposal, access to information becomes a key factor in their political identity construction. Many tribal members feel that when the project was first considered, PFS and the tribal chairman at the time Leon Bear (actor) lied, purposely withheld information, and left many questions unanswered (actions). "PFS is behind invisible walls down there" (Interview 6, June 6, 2002). As tribal members, many feel they have a right to information about the proposal yet "information has not come about to the people, and that's what they want" (Wash, as cited in Nuclear Regulatory Commission, 2002b). Specifically, the lease agreement between the tribe and the PFS consortium is of concern to tribal members. "They talk about the money that has been involved with Skull Valley Tribe and PFS. I still have not yet seen the lease. And as me being a member and them wanting to build this facility on the place that I call my home, I think I have a right to see this lease" (A. Bullcreek, as cited in Nuclear Regulatory Commission, 2002b). Only a few tribal members have been involved in the negotiations or been given all the correct information. This is in direct conflict with tribal law: "By law every tribal member has to look at that lease and approve it. By law" (Blackbear as cited in Verdioa, 2001). This is also in direct conflict with tribal tradition: "our traditional government in the past always informed us about issues that were going on. With the MRS and PFS facilities, most of us don't know what is going on" (Interview 8, March 31, 2000). Denial of access and the change in tribal procedures contradicts traditional approaches to decision-making and conflicts with tribal policy. This is seen as detrimental to the political structure of the tribe. Tribal members feel they are left out of decisions that directly affect them and are unable to control their own political future, resulting in their victimization at the hand of tribal leaders. "Withholding one's political voice, therefore, amounts to a forfeiture of self-determination" and power to act (Huspek and Kendall, 1991, p. 1). Nuclear waste policy development becomes an act of emplotment. Actions taken by actors Bear and the PFS become in Ricoeur's (Ricoeur, 1989) words, "subject to approval or disapproval" and they as actors and agents become "subject to praise or blame" (p. 164). In this case, Bear's actions are met with disapproval and he is subject to blame.

Senecah (2004) argues that access refers not only to information but the feeling of safety. Safety became a major concern to many tribal members.

I wish somebody would show me some papers with some facts or tell me something about how big this facility's supposed to be, you know. What are the dangers that we're facing? I don't know. I don't have any information about what's going on with this facility. I would think that they would tell me, you know, what's going on (L. Bullcreek, as cited in Nuclear Regulatory Commission, 2002b).

This quote from a tribal member insinuates that Bear has the information but is purposely withholding it from tribal members, placing them in danger. Another tribal member stated, "I do not have that much faith in the guarantees that our Skull Valley executive committees are given as far as the information about how safe these fuel rods are" (Nuclear Regulatory Commission, 1999). What tribal members need to make an informed decision are facts: answers about the safety of the nuclear waste, the terms of the lease, the nature of the relationship between PFS and the tribe, and the level of involvement tribal members would have in the management and maintenance of the waste.

Some tribal members feel that in addition to information, the tribal council withheld the allocation of resources, unfairly distributing them only to those who supported the proposal. "They're telling the people, 'If you speak up against us you're not going to receive anything.' Only the people that are for it get privilege" (M. Bullcreek, as cited in Nuclear Regulatory Commission, 2000). Another tribal member commented, "everyone who supports the facility has a new truck - if you don't support Leon, you don't have anything" (Bullcreek as cited in Dickson, 2000, p. 1). The discrepancy in tribal members' access to material resources is again blamed on Bear as tribal members are continually victimized by the political structure created by those in power.

Access to information and resources also constructs the political identity of those in support of the project. Bear, the tribal chairman at the onset of the project, denies that tribal members were not informed or given access to data. "All the terms of the PFS lease were discussed in the tribal membership meetings" (as cited in Hengesbaugh, 2000, p. 24). Other members of the tribal executive committee also argue they provided updates at every meeting.

The Executive Committee began educating the Tribal member about this in 1989. They felt like DOE was going to push this down our throats and put it on an Indian reservation like lots of other things they do. So, we began educating ourselves to prevent that from happening. We brought all this information to the council in 1990. We shared with them what the benefits and primary/ secondary cost breakdowns. (Interview 2, May 12, 2002)

Tribal members also speak of how information was shared with the tribe in variety of avenues. "All members who attended the general council meetings got the scoop on nuclear materials, how they are handled and stored through videos and reports" (J. Bear, as cited in Nuclear Regulatory Commission, 2002a). Tribal members are not victimized and caused to suffer at the hands of Bear and the PFS, but instead are agents, empowered and encouraged, to act for themselves and learn about the proposal and nuclear waste. "I can't recall any time when we weren't encouraged to find out for ourselves. I have watched how leaders have educated themselves on issues and the MRS plan" (Interview 12, June 7, 2002). Another tribal member said, "we've always been encouraged to find out for ourselves how this would work. For instance, I got to spend 41 days at a Prairie Island internship. I worked on a program with a Radiation Protection focus" (Interview 1, June 7, 2002). The identity narrative told by these tribal members is not one of confinement and exclusion but of encouragement, empowerment, and access. In their narratives, actions taken by tribal leaders become subject to approval and tribal leaders become subject to praise, not blame. In both cases, 
those who support the project and those who oppose it, access to information becomes a basis for power to voice concerns and act in self-determination, thus becoming a vital part of their political identity (Couldry, 2010; Maillé and Saint-Charles, 2014).

\section{Narratives of Standing}

In Senecah's (Senecah, 2004) “Trinity of Voice," standing refers to respect and the feeling of being heard. At the onset of the project, many tribal members felt that their tribal chairman Leon Bear would not listen to viewpoints that contradicted his own and stifled their opportunity to be heard. "We are all members there at Skull Valley and so if we decide not to have it ... this is where we are right now and it's not being heard. They are not listening to the people that are saying no" (A. Bullcreek, as cited in Nuclear Regulatory Commission, 2002b). Another tribal member claimed, "we should be heard. You should give us that opportunity to be able to say that we are against this" (M. Bullcreek, as cited in Nuclear Regulatory Commission, 2002b). These tribal members believe council meetings were to be a forum for sharing opinions, but those who oppose storing nuclear waste on their reservation feel they have not been allowed to share their concerns at meetings or given equal voice.

The people really haven't been given that choice, so this is not fair. There have been some supporters for Leon at the meetings, but our opposition has not been given equal time because they won't allow us to speak in the meetings. There are lots of people out there who oppose this. They have told me so, but they are afraid to speak up. (Interview 17, March 15, 2001)

Tribal members become afraid to speak up because their concerns have not been listened to, their opinions not ratified, and standing was not given. Some who have spoken against the proposal have been charged with sedition and politically punished by Bear and the tribal council. "We should have the right to speak out, but now they are calling it treason. What are we, back in the days of the buccaneers?" (Bullcreek as cited in Israelsen, 2003, para. 2). Tribal members feel fear and hopelessness and are constrained to act viewing themselves as the sufferers, to use Ricoeur's terminology, of Bear's actions and the social political conditions on the reservation.

Not only do tribal members feel they have been left out of the decision-making process but their desires have been misrepresented, further disrespecting them as tribal members and challenging their political standing in the tribe. "PFS and Leon and the council were always notifying people that the whole people in the tribe was for this facility. But that's not so" (A. Bullcreek, as cited in Nuclear Regulatory Commission, 2002b). Leon Bear and the PFS distorted the wishes of tribal members, falsely peddling tribal consensus. "Our council tells you that they have the support of their people for this PFS, but they don't really have it" (M. Bullcreek, as cited in Nuclear Regulatory Commission, 2002b). Tribal members feel they continue to be ignored and left out of the political decision-making process, denied a voice in tribal matters, and misrepresented to the general public. Their concerns overlooked, they struggle for recognition: a vital part of identity construction (Ricoeur, 2005; Couldry, 2010). Through this struggle they become persecuted. "We have been victimized enough" (Bullcreek as cited in Fahys, 2011, p. 1). Ricoeur (1989) argues that in our identity narratives we "apply to actions a moral judgment of imputation" (p. 101). Through their narratives about standing, tribal members impugn the actions of their leaders, enabling them to interpret themselves as sufferers or victims.

Those who support the proposal also intricately link standing to political identity in their narratives but contest they were heard and that tribal decisions were endorsed by the tribe. "All they're looking for is what's good for us. They're sticking behind us with whatever we want to do" (Interview 9, June 4, 2002). This statement implies tribal leaders have listened to the desires of the tribe and are supporting their people as they develop nuclear waste management policy on the reservation. The actions of Bear and the PFS act to ratify tribal members as they are consistent with the desires of those tribal members. Couldry (2010) argues a person must have the necessary "status" if "one is to be recognized by others as having a voice" (p. 7). Those tribal members whose voices are heard feel supported by the tribe and their political identities are affirmed. They are given status and legitimate recognition and empowered as agents to act, therefore, confirming their standing as tribal members.

\section{Narratives of Influence}

Influence, the third aspect of "Trinity of Voice" is the ability to influence decisions through a democratic process (Senecah, 2004). Tribal members opposed to storing nuclear waste on their reservation believe there has been no democratic process in relation to nuclear waste policy development. "You talk about democracy. We are supposed to have democracy on the reservation. Well, we don't even have that" (M. Bullcreek, as cited in Nuclear Regulatory Commission, 2000). They believe those in favor of the proposal are "taking advantage of the lack of a constitution and by-laws. They're just coming up with their own resolutions and passing them" (Interview 13, March 15, 2001). In the past as a traditional government, policy was brought before the tribal members and voted upon, but with the onset of the nuclear waste proposal, some members believe the political structure of the tribe changed.

We're a politically traditional government, so in that way we're unique. Resolutions are passed by a majority, half or more of voting members. Before the passage of something, it comes before the tribe. Members review resolutions or proposals. That's the traditional way of government. Since the MRS project, our traditional government started to change. Resolutions were being passed by less than half majority votes. Meetings were occurring after meetings were adjourned. (Interview 6 , June 6, 2002)

Tribe members feel they are no longer given the opportunity to vote, but are left out of decisions as policy was developed behind closed doors. "Our government structure changed when the Tribal Council started looking into the Monitored Retrievable Storage facility program. There was a change in structure at the 
time, and now the Council is saying that they don't need quorum to vote. This is not our traditional government" (Interview 8, March 31, 2000). Traditional forms of decision-making, a democratic vote and tribal code have been disregarded: Couldry (2010) argues that effective voice must have influence, and this is crucial to the legitimacy of any governing process. According to tribal members, they have no influence on political matters relating to the nuclear waste proposal. Bear has undermined the traditional form of government, leaving tribal members without an effective or legitimate voice.

Not all tribal members feel a lack of influence on the process of nuclear waste policy development. "We are a democracy here. We all vote on it" (Interview 11, May 15, 2002). A document put out by tribal leaders states, "We know that informed decisions which are in the best interests of our people and are made with their consent will not always be popular with everyone. Leadership is not a popularity contest" (Skull Valley Goshute Report, 1993, p. 43). This statement makes it clear that consent for the proposal was granted even if it was not the favored position. By supporting the proposal, tribal leaders are fulfilling their political duties. Chastising those who criticize the direction the tribe has taken, Bear refers to their efforts to stop the proposal as "an anarchist attempt ... to undermine the legitimate government of the Skull Valley Band of Goshutes" (as cited in Israelsen, 2001d, p. B2), impugning the naysayers and confirming his own actions in support of the proposal.

The above narrative analysis demonstrates how the process and structural aspects of the trinity of voice (access, standing, and influence) work together to either empower tribal members confirming a sense of their narrated political identity, or constrain tribal members negating their political identity. Illustrating how tribal members are sanctioned or inhibited by a political process provides only a partial analysis. What remains to be demonstrated is how tribal members negotiate their identity in relation to political structures. For, as suggests Ricoeur (1991a), we do not passively respond to political structures and share those responses in our narratives. We continually construct our identity through the perpetual weaving and reweaving of past and present narratives in a dialectical relationship between what he terms sameness and selfhood.

\section{Narratives of Voice: A Synthesis of Sameness and Selfhood}

The crux of understanding identity formation through narrative has to do with Ricoeur's concepts of sameness and selfhood. Ricoeur contends that to have an identity one conceptualize oneself as similar yet distinct from others and as continuous over time only through the narratives one tells. In this process, people have what he terms sameness, the fixed parts of one's identity (i.e., race, gender, birthplace, etc.) as well as one's habits and traits of character. Sameness not only describes the constant set of dispositions but also similarities with others who share the same attributes, for as argues Ricoeur (1992), sameness is "the concept of relation and a relation of relations" (p. 116).

Although there is consistency through familiarity, identities are continually in flux and open to change. Ricoeur argues the other dimension of identity is selfhood or self-constancy. Selfhood is the aspect of human identity that is unfinished, open to change, and in an ongoing dialog between current experience and past memory. It accounts for a "modality of awareness that allows for development and change while simultaneously providing a form of self-constancy" (Joy, 1997, p. xxix). Constancy, implying dependability or reliability, takes on an ethical dimension. It is, in a sense, a person's accountability of self to others, which is maintained in spite of alteration or change. "The pole of selfhood, or identity in spite of diversity, is responsibility, or acting in such a manner that others can count on me and thus make me accountable for my actions" (Regan, 1996, p. 86). Selfhood then, is the ethical answerability of one's actions to self and others.

According to Ricoeur, identity is constructed in the relational dimensions of consistency of traits (sameness) and constancy of change (selfhood). "Identity is between the poles of sameness as character and selfhood as responsibility" (Regan, 1996, p. 86). The task of narrative is to mediate between these two poles of identity, to balance sameness and selfhood and to anchor identity in personal and social history and current experience. Personal narratives act to create consistency or sameness of a recognizable self while at the same time justify change and articulate constancy or selfhood. According to Ricoeur (1992), "It is within the framework of narrative theory that the concrete dialectic of selfhood and sameness attains its fullest development" (p. 114). It is through narrative that one constantly creates, constructs, changes, and justifies one's identity.

Political narratives of voice (access, standing, and influence) reveal the intricacy and importance of the decision to store nuclear waste on the Skull Valley reservation and its implications to not only the political and environmental future of the tribe but the very identity of tribal members. Narratives subtly, yet powerfully, work to confirm or negate tribal members' sense of sameness and selfhood and thus their identity.

For some tribal members, sameness (similarity with others and constancy of self) is threatened by the nuclear waste proposal. In the above quotes, many tribal members feel they are not being treated equally; only a few members of the tribe have information regarding the MRS proposal, only those members who support the proposal get to voice their opinions in tribal meetings, and only some members get to be a part of the political decision-making process that directs their future. The partiality of their political situation threatens their sense of sameness; they are not being treated similarly to other tribal members and relations of equality are threatened. For others, however, they feel a sense of equality and sameness brought about by the proposal, as well as the opportunity to become educated and have a say in important decisions their tribe will make.

Perhaps the most telling indication of the impact of nuclear policy development on tribal members is their narratively constructed selfhood (ethical accountability to self and others). If a tribal member feels disempowered to act, that his or her actions are hindered by others or the political conditions, they become vulnerable and cannot be accountable to self and others. One tribal member stated,

To me it's embarrassing now because people ask me where I'm from and I say Skull Valley, and they says, 
"Well, you're the people putting the facility out there. Why are you doing that for?" I says, "I'm not doing it. I'm trying to go against it. I don't believe in it." But I just wanted to, you know, say these things because I read these newspapers about the chairman, Leon Bear, saying he speaks for the tribe. Well, he doesn't speak for me. I live out in Skull Valley and I'm here to speak for myself. (Nuclear Regulatory Commission, 1998)

The nuclear waste proposal becomes embarrassing, limiting this tribal member's ability to answer for herself to others. Ethical accountability of self cannot be attained. Selfhood is compromised and identity is threatened. What is of particular interest in the above quote is the tribal member's desire to rectify the challenge to her selfhood through her narrative. In the beginning of the quote, she speaks to the restraining nature of the project but in the end of her quote she seizes the opportunity to claim her voice and speak for herself. This may seem a contradiction; however, Ricoeur argues that it is through narrative that individuals seek to remedy contradictions in their lived experience and make sense of events in their lives (Venema, 2000). The undertaking of narrative is to balance consistency of self (sameness) with accountability to others (selfhood) in the continual construction of identity.

Selfhood is also implicated for those who support the project. Empowered by the situation and encouraged to learn and act, they have taken ownership of the proposal and the political circumstance. These tribal members do not feel excluded in the decision-making process nor do they feel powerless to act. "The Native American is just a small pea in a bucket. But yet we're big enough to where we can help, help out the people or help out the world, help out the United States, say, look at us now, we're here to help" (G. Bear, as cited in Nuclear Regulatory Commission, 2002a). Accountability to others is confirmed with an opportunity to help, brought about by the proposal. Selfhood is thus not threatened, but sustained. To attain selfhood through narrative, tribal members need the opportunity to answer for themselves in a way that is consistent with their idea of who they are.

According to Ricoeur, in order to create identity, there must be a synthesis of sameness and selfhood. If either or both of these elements are compromised, identity becomes challenged. The task of narrative is to attempt to balance these aspects in relation to ongoing experience. Whether tribal members feel that they have been empowered or victimized by the proposal to house nuclear waste on their reservation, their narratives work to balance their sense of sameness and selfhood as they continually construct their political identity in relation to the political structures of access, standing, and influence.

\section{CONCLUSION AND THEORETICAL CONTRIBUTIONS}

This article contributes to our theoretical understanding of the interplay between narrative, voice, and identity, revealing its implications for nuclear waste policy development. Through a narrative analysis of Goshute discourse about the nuclear waste project, we can understand the impact of those processes on the construction of tribal members' political identity. Political processes must afford opportunities for affirmation and ratification of an individual's need to connect with others and maintain a consistency of self (sameness) as well as provide for individuals to be accountable to self and others (selfhood). If the nuclear waste proposal presents process or structural opportunities to give input (access, standing, and influence), voice is attained and tribal members become agents and are empowered. However, if a policy process does not grant this opportunity, the political identity of those involved is threatened and the forum for tribal nuclear waste policy development and decision-making becomes compromised. "If through an unequal distribution of narrative resources, the materials from which some people build their account of themselves are not theirs to adapt or control, then this represents a deep denial of voice, a deep form of oppression" (Couldry, 2010, p. 9). If the project limits their voice, then tribal members become victims of the actions of others, or in Ricoeur's words, sufferers. For "to deny value to another's capacity for narrative - to deny her potential for voice - is to deny a basic dimension of human life" (Couldry, 2010, p. 7). We can also understand the impact of policy development processes on other native and non-native community members' identities as well. For as argues Couldry (2010), "we are all engaged in struggles for recognition" (p. 130). Understanding how political voice gets negotiated and the recognition of political self becomes a crucial part of understanding policy development.

This study also provides a deeper understanding of the complexities of environmental conflicts within Native American communities. Political theorist Whitebrook (2001) contends that as a product of political context, the self in narrative acts in response to political conditions and existing power relations and hierarchies. Thus positioning of oneself within a story creates discursive leverage and autonomy. Realizing the dynamics of political identity is key in understanding the dynamics of political conflict. "Identity narratives are weapons in the struggle for power" (Schiffrin, 1996, p. 197). Analysis of the implications of voice and identity "continues to be useful, especially in contexts where long-entrenched inequality of representation needs to be addressed" (Couldry, 2010, p. 1). As with members of the Goshute tribe, without participatory decision-making from those whom are governed by policy-without voice and ownership brought about by access, influence, and standing-political identity is threatened and political decisions can become a catalyst for political conflict.

In this new era of waste management and the Office of Nuclear Energy's commitment to community engagement and collaborative consent-based siting, understanding how tribal members negotiate voice within internal tribal decision-making processes and the implications of those negotiations becomes critical and timely. Couldry (2010) calls for an analysis of the barriers to political voice and asks that we "uncovering the processes which obstruct voice and allow some types of voice to emerge as possible and others not, and reflecting on how those processes might be resisted" (p. 3). He continues, political voice is undermined when,

collective voices or institutional decisions fail to register individual experience; when institutions ignore collective views; when distributed voice is not reflected in 
opportunities to redeem voice in specific encounters. Above all, voice is undermined when societies become organized on the basis that individual, collective and distributed voice need not be taken into account, because a higher value or rationality trumps them. (Couldry, 2010, p. 10)

To fully engage communities in a collaborative consent-based process, the Office of Nuclear Energy must exclude practices that undermine opportunities for voice and do not take into account the importance of political identity. They must instead support structural processes for granting voice (access, standing, and influence) and discriminate "in favor of ways of organizing human life and resources that, through their choices, put the value of voice into practice, by respecting the multiple interlinked processes of voice and sustaining them, not undermining or

\section{REFERENCES}

Agrawal, A. (1995). Dismantling the divide between indigenous and scientific knowledge. Dev. Change 26, 413-439. doi:10.1111/j.1467-7660.1995. tb00560.x

Alasuutari, P. (1995). Researching culture: Qualitative method and cultural studies. London: SAGE.

Alley, W. M., and Alley, R. (2014). The growing problem of stranded used nuclear fuel. Environ. Sci. Technol. 48, 2091-2096. doi:10.1021/es405114h

Beierle, T. C., and Cayford, J. (2002). Democracy in Practice: Public Participation in Environmental Decisions. Washington, DC: Resources for the Future.

Blowers, A. (2000). "Landscapes of risk: conflict and change in nuclear oasis," in Landscapes of Defense, eds J. R. Gold and G. Revill (Essex, England: Prentice Hall), 21-47.

Boholm, A., and Lofstedt, R. (2004). Facility Siting: Risk, Power and Identity in Land Use Planning. London, England: Earthscan.

Brown, D. D. (1997). "On narrative and belonging," in Paul Ricoeur and Narrative. Context and Contestation, ed. M. Joy (Calgary, AB: University of Calgary Press), 109-120.

Bruner, J. S. (1996). The Culture of Education. Boston, MA: Harvard University Press.

Burger, J., Harris, S., Harper, B., and Gochfeld, M. (2010a). Ecological information needs for environmental justice. Risk Analysis 30, 893-905. doi:10.1111/j.1539-6924.2010.01403.x

Burger, J., Powers, C., and Gochfeld, M. (2010b). Regulatory requirements and tools for environmental assessment of hazardous wastes: understanding tribal and stakeholder concerns using Department of Energy sites. J. Environ. Manage. 91, 2707-2716. doi:10.1016/j.jenvman.2010.07.028

Burr, T. (2011). Matheson fears high-level N-waste could head to Utah. Salt Lake Tribune, 18th August.

Carbaugh, D. (1996). Situating Selves: The Communication of Social Identities in American Scenes. New York, NY: State University of New York Press.

Cates, K. (1998). Goshutes see gold in nuclear waste. Planned storage site may be matter of survival for tribe. Deseret News, 25th January.

Cesspooch, C. R. (1998). Threat to tribal sovereignity. Salt Lake Tribune. 7th June.

Chen, Y. W., Milstein, T., Anguiano, C., Sandoval, J., and Knudsen, L. (2012). Challenges and benefits of community-based participatory research for environmental justice: a case of collaboratively examining ecocultural struggles. Environ. Commun. 6, 403-421. doi:10.1080/17524032.2012.698291

Clarke, T. (2002). An ideographic analysis of Native American sovereignty in the state of Utah: enabling denotative dissonance and constructing irreconcilable conflict. Wicazo Sa Review 17, 43-63. doi:10.1353/wic.2002.0015

Clarke, T. (2008). Native Americans and Nuclear Waste: Narratives of Conflict. Germany: VDM Verlag Publishing.

Clarke, T. (2010). Goshute Native American tribe and nuclear waste: complexities and contradictions of a bounded-constitutive relationship. Environ. Commun. 4, 387-405. doi:10.1080/17524032.2010.520724 denying them" (Couldry, 2010, p. 2). This will allow for the political identities of community members to be confirmed or ratified, build trust with and within communities and ensure socially legitimate policy (Huspek and Kendall, 1991; Phillips and Carvalho, 2012).

\section{ETHICS STATEMENT}

Research interviews complied with the IRB consent for interviews approved by the University of Utah Humans Subject Review Board.

\section{AUTHOR CONTRIBUTIONS}

The author confirms being the sole contributor of this work and approved it for publication.

Clarke, T., Rodriguez, D., and Alamillo, J. (2015). Engaging Latino/a communities in National Park programs: building trust and providing opportunities for voice. Environ. Manag. Sustain. Dev. 4, 136-148. doi:10.5296/emsd. v4i1.7109

Costanzo, J. (1999). "No N-waste," Goshutes say. 25 join suit to have lease declared void. Deseret News, 11th March.

Couldry, N. (2010). Why Voice Matters: Culture and Politics after Neoliberalism. London: SAGE.

Cox, R. (2006). Environmental Communication and the Public Sphere. Thousand Oaks, CA: SAGE.

Deloria, V. (1985). Behind the Trail of Broken Treaties: An Indian Declaration of Independence. Austin, TX: University of Texas Press.

Depoe, S., and Delicath, J. W. (2004). "Introduction," in Communication and Public Participation in Environmental Decision Making, eds S. Depoe, J. W. Delicath, and M. A. Elsenbeer (Albany, NY: SUNY Press), 1-12.

Dickson, M. (2000). Nukes for Goshutes? Opposition to a high-level waste dump is mounting, but is it too late? City Weekly, pp. 1-2, 20-25, 14th September.

Dirlik, A. (2000). "The past as legacy and project: postcolonial criticism in the perspective of indigenous historicism," in Contemporary Native American Political Issues, ed. T. R. Johnson (Lanham, MD: AltaMira Press), 73-98.

Endres, D. (2009a). From wasteland to waste site: the role of discourse in nuclear power's environmental injustices. Local Environ. 14, 917-937. doi:10.1080/13549830903244409

Endres, D. (2009b). The rhetoric of nuclear colonialism: rhetorical exclusion of American Indian arguments in the Yucca mountain nuclear waste siting decision. Commun. Crit. Cult. Stud. 6, 39-60. doi:10.1080/1479142080 2632103

Endres, D. (2009c). Science and public participation: an analysis of public scientific argument in the Yucca mountain controversy. Environ. Commun. 3, 49-75. doi: $10.1080 / 17524030802704369$

Fahys, J. (2002a). Feds recognize Bear as Goshute leader. Salt Lake Tribune, 2nd April.

Fahys, J. (2002b). Feds rule against anti-waste Goshutes. Salt Lake Tribune, 2nd October.

Fahys, J. (2003). Goshutes who have opposed nuclear waste are out in cold. Salt Lake Tribune, 6th January.

Fahys, J. (2007). Goshutes, state renew fight over Tribe's nuclear waste storage plans. Salt Lake Tribune, 3rd May.

Fahys, J. (2011). Don't dump nuclear waste on us, Westerners say. Salt Lake Tribune, 14th September.

Funk, A., and Sovacool, B. K. (2013). Wasted opportunities: resolving the impasse in United States nuclear waste policy. Energy Law J. 34, 113-147.

Geertz, C. (1976). "From the native's point of view: on the nature of anthropological understanding," in Meaning in Anthropology, eds K. Basso and H. A. Selby (Albuquerque, NM: University of New Mexico Press), 221-237.

Grand, S. (2004). Red Pedagogy: Native American Social and Political Thought. Lanham, MD: Rowman and Littlefield Publishing Inc. 
Harper, K. M. (2001). Introduction: the environment as master narrative: discourse and identity in environmental problems. Anthropol. Q. 74, 101-103.

Hengesbaugh, M. (2000). Nuclear powwow. The Skull Valley Goshutes toxic dump proposal pits Goshute against Goshute in a struggle over sovereignty. City Weekly,16th March.

Huspek, M., and Kendall, K. E. (1991). On withholding political voice: an analysis of the political vocabulary of a "nonpolitical" speech community. Q. J. Speech 77, 1-19. doi:10.1080/00335639109383939

Israelsen, B. (2000a). On the hot seat: Goshutes to put leader, nuke deal to a vote. Salt Lake Tribune, 4 th November.

Israelsen, B. (2000b). Tribe keeps pro-waste chairman. Salt Lake Tribune, 28th November.

Israelsen, B. (2001a). Goshute rivals stake a claim to leadership. Salt Lake Tribune, p. A1, 29th August.

Israelsen, B. (2001b). Scuffle threatens to push Goshutes deeper into divisive power struggles. Salt Lake Tribune, p. A1, 1st September.

Israelsen, B. (2001c). Is Bear or Moon real leader of Goshutes? Salt Lake Tribune, p. B2, 17 October.

Israelsen, B. (2001d). Nation inserts itself into tribal fray. Salt Lake Tribune, p. B2, 13th November.

Israelsen, B. (2003). Goshutes still in political disarray. Salt Lake Tribune, 30th April.

Joy, M. (1997). Paul Ricoeur and Narrative: Context and Contestation. Calgary, AB: University of Calgary Press.

Kemp, D. (1999). Fear dominates N-waste hearing. Deseret News, 30th April.

Kinsella, W. J. (2004). "Public expertise: a foundation for citizen participation in energy and environmental decisions," in Communication and Public Participation in Environmental Decision Making, eds S. Depoe, J. W. Delicath, and M. A. Elsenbeer (Albany, NY: SUNY Press), 83-98.

Klassen, J. A., and Feldbausch-Parker, A. M. (2011). Oiling the gears of public participation: the value of organizations in establishing trinity of voice for communities impacted by the oil and gas industry. Local Environ. 16, 903-915. doi:10.1080/13549839.2011.615305

Kuletz, V. (1998). The Tainted Desert: Environmental and Social Ruin in the American West. New York, NY: Routledge.

LaDuke, W. (2001). "Indigenous environmental perspectives: a North American primer," in Native American Voices. A Reader, 2nd Edn, eds S. Lobo and S. Talbot (Upper Saddle River, NJ: Prentice Hall), 353-368.

Lewis, D. R. (1995). Native Americans and the environment: a survey of twentieth-century issues. Am. Indian Q. 19, 433. doi:10.2307/1185599

Lewis, D. R. (2007). "Skull Valley Goshutes and the politics of nuclear waste," in Native Americans and the Environment, eds M. E. Harkin and D. R. Lewis (Lincoln, NE: University of Nebraska Press), 304-342.

Maillé, M-Ė, and Saint-Charles, J. (2014). Fuelling and environmental conflict through information diffusion strategies. Environ. Commun. 8, 305-325. doi:10.1080/17524032.2013.851099

Martin, T. (2007). Muting the voice of the local in the age of the global: how communication practices compromise public participation in India's Allain Dunhangan environmental impact assessment. Environ. Commun. 1, 171-193. doi:10.1080/17524030701642595

Nadasdy, P. (1999). The politics of Tek: power and the "integration" of knowledge. Arctic Anthropol. 36, 1-18.

Nagel, J. (1996). American Indian Ethnic Renewal: Red Power and the Resurgence of Identity and Culture. New York, NY: Oxford University Press.

Nelson, B. R. (2014). Tribe-sanctioned nuclear waste facilities and their involuntary neighbors. Columbia J. Race Law 4, 257-282.

Pajo, J. (2016). Two paradigmatic waves of public discourse on nuclear waste in the United States, 1945-2009: understanding a magnitudinal and longitudinal phenomenon in anthropological terms. PLOS ONE 11:e0157652. doi:10.1371/ journal.pone.0157652

Peeples, J., Krannich, R. S., and Weiss, J. (2008). Arguments for what no one wants: the narratives of waste storage proponents. Environ. Commun. 2, 40-58. doi:10.1080/17524030701642751

Peeples, J. A., and Depoe, S. P. (eds) (2014). "Introduction: voice and the environment-critical perspectives," in Voice and Environmental Communication (New York, NY: Palgrave Macmillan), 1-17.

Phillips, L., and Carvalho, A. (2012). "Introduction," in Citizen Voices: Performing Public Participation in Science and Environmental Communication, eds L. Phillips, A. Carvalho, and J. Doyle (Bristol: Intellect), 1-17.
Regan, C. (1996). Paul Ricoeur: His Life and His Work. Chicago, IL: University of Chicago Press.

Ricoeur, P. (1983). Time and Narrative, Vol. 1. Chicago, IL: University of Chicago Press.

Ricoeur, P. (1984). Time and Narrative, Vol. 2. Chicago, IL: University of Chicago Press.

Ricoeur, P. (1985). Time and Narrative, Vol. 3. Chicago, IL: University of Chicago Press.

Ricoeur, P. (1989). "Humans as the subject matter of philosophy," in The Narrative Path, eds P. Kemp and D. Rasmussen (Cambridge, MA: Cambridge University Press), 89-97

Ricoeur, P. (1991a). "Life in quest of narrative," in On Paul Ricoeur: Narrative and Interpretations, ed. D. Wood (New York, NY: Routledge), 20-33.

Ricoeur, P. (1991b). "Narrative identity," in On Paul Ricoeur: Narrative and Interpretation, ed. D. Wood (New York, NY: Routledge), 188-199.

Ricoeur, P. (1992). Oneself as Another. Chicago, IL: The University Chicago Press.

Ricoeur, P. (2005). The Course of Recognition. Cambridge, MA: Harvard University Press.

Riley, P. (2004). Nuclear Waste: Law, Policy and Pragmatism. England: Ashgate Publishing Limited.

Rosa, E. A., and Short, J. F. (2004). "The importance of context in the siting controversies: the case of high-level nuclear waste disposal in the US," in Facility Siting: Risk, Power and Identity in Land Use Planning, eds A. Boholm and R. Lofstedt (London, England: Earthscan), 1-20.

Santini, J. (2001). Goshutes hold election, but no one declared a winner yet. Salt Lake Tribune, 24th September.

Schiffrin, D. (1996). Narrative as self-portrait: sociolinguistic constructions of identity. Lang. Soc. 25, 167-203. doi:10.1017/s0047404500020601

Senecah, S. (2004). "The trinity of voice: the role of practical theory in planning and evaluating the effectiveness of environmental participatory processes," in Communication and Public Participation in Environmental Decision Making, eds S. Depoe, J. Delicath, and M.-F. Elsenbeer (Albany, NY: State University of New York Press), 13-33.

Singh, N., Koku, J. E., and Balfors, B. (2007). Resolving water conflicts in mining areas of Ghana through public participation. J. Creat. Commun. 2, 361-382. doi:10.1177/097325860700200306

Skull Valley Goshute Report. (1993). Retrieved from Utah. Skull Valley, UT: Skull Valley Goshute Tribe.

Sovacool, B. K., and Funk, A. (2013). Wrestling with the Hydra of nuclear waste in the United States. Electricity J. 26, 67-78. doi:10.1016/j.tej.2013.01.008

Spangler, J. (1998). Leavitt calls in his troops to fight $\mathrm{N}$-waste plans. Deseret News, 3rd June.

Stöhr, C., Lundholm, C., Crona, B., and Chabay, I. (2014). Stakeholder participation and sustainable fisheries: an integrative framework for assessing adaptive comanagement processes. Ecol. Soc. 19, 1-14. doi:10.5751/es-06638-190314

Taylor, B. C. (2003). Nuclear waste and communication studies. Rev. Commun. 3, 285-291. doi:10.1080/0308399

Taylor, B. C., and Kinsella, W. J. (2007). "Linking nuclear legacies and communication studies," in Nuclear Legacies: Communication, Controversy and the U.S. Nuclear Weapons Complex, eds B. C. Taylor, W. J. Kinsella, S. Depoe, and M. Metzler (Lanham, MD: Lexington Books), 1-37.

Taylor, B. C., Kinsella, W. J., Depoe, S., and Metzler, M. (2005). "Nuclear legacies: communication, controversy and the U.S. nuclear weapons controversy," in Communication Yearbook, Vol. 29, ed. P. Kalbfleisch (Mahwah, NJ: Lawrence Erlbaum), 363-409.

Urbani, D. (2003). Goshute duo fights to protect status. 2 fear actions after they questioned leader's authority. Deseret News, 12th July.

Venema, H. I. (2000). Identifying Selfhood: Imagination, Narrative, and Hermeneutics in the Thoughts of Paul Ricoeur. New York, NY: State University of New York Press.

Verdioa, K. (Writer). (2001). Skull Valley: Radioactive Waste and the American West. In KUED (Producer). Salt Lake City, UT.

Walker, G., Senecah, S. L., and Daniels, S. E. (2006). From the forest to the river: citizen's views of stakeholder engagement. Hum. Ecol. Rev. 13, 193-202.

Watts, E. (2001). "Voice" and "voicelessness" in rhetorical studies. Q. J. Speech 87, 179-196. doi:10.1080/00335630109384328

Whitebrook, M. (2001). Identity, Narrative and Politics. New York, NY: Routledge.

Nuclear Regulatory Commission. (1998). Scoping Meeting for Preparation of an EIS for the Private Fuel Storage Facility, 2nd June. Available at: http://www. nrc.gov/docs/ML0103/ML010320348.pdf 
Nuclear Regulatory Commission. (1999). Official Transcript of Proceedings United States of America Nuclear Regulatory Commission Scoping Meetings for the Private Fuel Storage Facility Environmental Impact Statement, April 29. Available at: http://www.nrc.gov/docs/ML0103/ML010330178.pdf

Nuclear Regulatory Commission. (2000). Transcript of July 27, 2000, public meeting on the P draft environmental impact statement for the Provate Fuel Storage Facility, Salt Lake City, Utah. Docket No.: 72-22, 27 July. Available at: http:// pbadupws.nrc.gov/docs/ml0037/ML003769776.pdf

Nuclear Regulatory Commission. (2002a). Transcript of Hearing (Limited Appearance Session) Held in Tooele, Utah; Docket No. 72-22. $6^{\text {th }}$ April. Available at: http://www.nrc.gov/docs/ML0213/ML021360289.pdf

Nuclear Regulatory Commission. (2002b). Transcript of Limited Appearance Session on April 8, 2002, in Salt Lake City, Utah; Docket No. 72-22. Available at: http://www.nrc.gov/docs/ML0211/ML021140170.pdf
Nuclear Regulatory Commission. (2012). Report to the Secretary of Energy. Available at: http://www.energy.gov/sites/prod/files/2013/04/f0/brc_finalreport_jan2012.pdf

Conflict of Interest Statement: The author declares that the research was conducted in the absence of any commercial or financial relationships that could be construed as a potential conflict of interest.

Copyright ( $(2017$ Clarke. This is an open-access article distributed under the terms of the Creative Commons Attribution License (CC BY). The use, distribution or reproduction in other forums is permitted, provided the original author(s) or licensor are credited and that the original publication in this journal is cited, in accordance with accepted academic practice. No use, distribution or reproduction is permitted which does not comply with these terms. 